\title{
NBS1 Mutation and prognosis of Prostate Cancer
}

\author{
Dominika Wokołorczyk*, Wojciech Kluźniak, Cezary Cybulski, Jan Lubiński \\ From Annual Conference on Hereditary Cancers 2012 \\ Szczecin, Poland. 30-31 August 2012
}

Inherited factors contribute to the burden of prostate cancer, however the identification of susceptibility genes for prostate caner has been challenging. To establish the contribution of eight founder alleles in three DNA damage repair genes (BRCA1, CHEK2 and NBS1) to prostate cancer in Poland, and to measure the impact of these variants on survival among patients, 3750 men with prostate cancer and 3956 cancer-free controls were genotyped for 3 founder alleles in BRCA1 (5382insC, 4153delA, C61G), 4 alleles in CHEK2 (1100delC, IVS2 $+1 G>A$, del5395, I157T), and 1 allele in NBS1 (657del5). Strong associations were seen for both CHEK2 and NBS1. BRCA1 was not associated with the risk of prostate cancer, NBS1 mutation was associated with poor survival - mortality was significantly worse for carriers of a NBS1 mutation than for non-carriers $(\mathrm{HR}=1.85 ; \mathrm{p}=$ 0.008 ). We conclude that a founder mutation in NBS1 predisposes to aggressive prostate cancer.

Published: 10 December 2012

doi:10.1186/1897-4287-10-S4-A29

Cite this article as: Wokołorczyk et al: NBS1 Mutation and prognosis of Prostate Cancer. Hereditary Cancer in Clinical Practice 2012 10(Suppl 4):A29.

Submit your next manuscript to BioMed Central and take full advantage of:

- Convenient online submission

- Thorough peer review

- No space constraints or color figure charges

- Immediate publication on acceptance

- Inclusion in PubMed, CAS, Scopus and Google Scholar

- Research which is freely available for redistribution

\section{Biomed Central}

